\title{
ANALISIS PROFITABILITAS OLAHAN KOPI ROBUSTA SEBAGAI PRODUK UNGGULAN KOPERASI TIRTO KENCONO DI KABUPATEN TANGGAMUS
}

\author{
(Profitability Analysis of Processed Robusta Coffee as a Superior Product at Tirto Kencono Cooperative in \\ Tanggamus District)
}

Laely Savitry, Teguh Endaryanto dan Ktut Murniati

Jurusan Agribisnis, Fakultas Pertanian, Universitas Lampung. Jl. Prof. Dr. Soemantri Brodjonegoro No. 1, Bandar Lampung, 35145, e-mail : teguh.endaryanto@fp.unila.ac.id

\begin{abstract}
This study aims to analyze income and profitability of processed robusta coffee as a superior product in Tirto Kencono Cooperative. The research method used in this study is a case study. Respondents in this study were manager, suppliers and all people related in the robusta coffee processing unit. The research was conducted at the Tirto Kencono Cooperative located in Talang 20 Village, Air Naningan Sub-District, Tanggamus District. Data collection was conducted in February 2019 and analyzed using quantitative descriptive analysis. The results of the research showed that the four products were viable and feasible because the R/C values were more than one on cash costs and total costs. Four products have profitability ratio of more than $0 \%$ with the highest profitability ratio was obtained by Green Coffee T20 product (77.40\%) and the lowest product was Gendis Coffee T20 (21.24\%).
\end{abstract}

Key words : income, profitability, robusta coffee

\section{PENDAHULUAN}

Indonesia memiliki tiga sektor kekuatan ekonomi untuk melaksanakan berbagai kegiatan dalam tatanan kehidupan perekonomian, yaitu sektor negara, sektor swasta, dan sektor koperasi. Koperasi merupakan salah satu pelaku ekonomi yang bersifat kerakyatan, sehingga koperasi dipandang cocok untuk perekonomian Indonesia.

Provinsi Lampung berada di urutan ke empat dengan jumlah koperasi aktif terbanyak di Sumatera tahun 2011-2016. Pada tahun 2016, jumlah koperasi yang aktif di Provinsi Lampung adalah 3.019 koperasi dan mengalami fluktuasi setiap tahunnya. Penambahan koperasi yang aktif selalu diikuti oleh penambahan koperasi yang tidak aktif [BPS 2016].

Menurut Dinas Koperasi dan UKM Provinsi Lampung (2017) terdapat jumlah koperasi di Provinsi Lampung sebanyak 4.914 unit dimana sebesar $45,50 \%$ koperasi dalam status aktif dan $54,50 \%$ koperasi dalam status pasif. Berdasarkan kuantitasnya, koperasi pasif lebih banyak dibandingkan koperasi aktif. Jumlah koperasi untuk setiap kabupaten mengalami fluktuasi yang cukup tinggi, seperti Kabupaten Tanggamus dengan jumlah koperasi dalam status aktif dan pasif yang setiap tahunnya berfluktuasi. Tahun
2017 terdapat 316 unit koperasi di Kabupaten Tanggamus dengan koperasi dalam status aktif sebesar $26,00 \%$ dan koperasi dalam status pasif sebesar $74,00 \%$. Koperasi dalam status pasif lebih banyak karena kinerja yang kurang dari koperasi tertentu dan pengelolaan koperasi yang dilaksanakan belum baik.

Kabupaten Tanggamus memiliki jumlah koperasi pasif lebih banyak dibandingkan koperasi aktif pada tahun 2017. Jenis koperasi terbagi menjadi Koperasi Unit Desa (KUD), Koperasi Perumahan Rakyat (KPR) dan Koperasi Pertanian (KOPTAN). Salah satu koperasi aktif yang berada di Kabupaten Tanggamus adalah Koperasi Tirto Kencono yang terletak di Kecamatan Air Naningan dan tergolong jenis Koperasi Pertanian (KOPTAN) terbesar di Kecamatan Air Naningan dalam bidang perkebunan kopi.

Koperasi Tirto Kencono merupakan salah satu koperasi pertanian yang terletak di Dusun Talang 20 Kecamatan Air Naningan Kabupaten Tanggamus. Koperasi ini dibentuk pada tahun 2013 dan memiliki Badan Hukum Nomor 221/BH/X.6/111/2014 tanggal 04 Maret 2014. Anggota dari koperasi tersebut yaitu petani kopi hutan rakyat sekaligus yang mengadakan bahan baku kopi robusta. Kopi yang dipasok oleh anggota koperasi dalam berbagai bentuk jenis kopi 
yaitu panen kopi merah, kopi hijau dan kopi campuran.

Masyarakat yang berada di Dusun Talang 20, mayoritas memiliki mata pencaharian sebagai petani kopi hutan rakyat dengan produksi kopi sebanyak 1.062 ton dengan luas panen 10.735 ha (Dinas Perkebunan dan Peternakan Kabupaten Tanggamus 2017). Usahatani kopi yang dilakukan merupakan hasil hutan rakyat dan sebagian besar merupakan anggota dari Koperasi Tirto Kencono. Rendahnya produktivitas komoditas kopi sebesar 0,99 kuintal/ha disebabkan oleh pemeliharan tanaman yang kurang intensif, bahan tanam bukan dari klon unggul, serangan hama/penyakit, atau umur tanaman yang sudah tua.

Petani kopi hutan rakyat lebih fokus terhadap usahatani kopi dan tanaman lainnya daripada melakukan pekerjaan lainnya untuk meningkatkan pendapatan. Petani dapat melakukan pengolahan hasil panen kopi mereka secara alami untuk menghasilkan biji kopi dengan kualitas yang baik, akan tetapi sulit untuk dilakukan mengingat rendahnya kemampuan dan pengetahuan petani untuk menghasilkan kualitas produk yang baik. Hal ini menyebabkan rendahnya industri pengolahan kopi robusta di Dusun Talang 20 dan menyebabkan pendapatan para petani kopi hutan rakyat tersebut sulit untuk ditingkatkan.

Rendahnya kemampuan dan pengetahuan petani dalam pengolahan kopi menyebabkan para petani lebih memilih menjual hasil usahataninya ke koperasi daripada tengkulak untuk menghindari permainan harga dan memenuhi kebutuhan unit usaha pengolahan kopi robusta di Koperasi Tirto Kencono dalam menghasilkan produk-produk unggulan koperasi. Akan tetapi permasalahan masih ditemukan pada unit pengolahan kopi, yaitu mayoritas para anggota memasok kopi campuran, sehingga diperlukan aktivitas lebih dalam proses pengolahannya yaitu sortasi.

Petani kopi hutan rakyat di Dusun 20 khususnya para anggota memanen dan menjual hasil usahataninya dalam bentuk kopi campuran. Hal ini karena lokasi usahatani di pegunungan yang menyebabkan sulitnya melakukan panen petik merah. Unit usaha tetap menerima pasokan bahan baku dalam bentuk petik merah, hijau dan campuran sebagai persediaan bahan baku, akan tetapi dibutuhkan biaya tambahan bagi tenaga kerja untuk melakukan sortasi. Olahan kopi robusta yang menjadi produk unggulan koperasi adalah
Fine Robusta T20, Roastbean Robusta T20, Green Coffee T20, dan Gendis Coffee T20.

Penambahan aktivitas tersebut akan berpengaruh terhadap biaya yang dikeluarkan. Semakin kecil biaya yang dikeluarkan, maka akan menghasilkan keuntungan yang tinggi, dan sebaliknya. Keuntungan yang diperoleh akan menentukan berapa besar profitabilitas masing-masing produk dan akan mengetahui olahan mana yang akan memberikan sumbangan profitabilitas terbaik. Penelitian ini bertujuan untuk menganalisis pendapatan dan menganalisis profitabilitas olahan kopi robusta menjadi produk unggulan Koperasi Tirto Kencono.

\section{METODE PENELITIAN}

Penelitian ini menggunakan metode studi kasus. Penelitian dilaksanakan pada unit usaha pengolahan kopi robusta di Koperasi Tirto Kencono yang terletak di Desa Talang 20, Kecamatan Air Naningan, Kabupaten Tanggamus. Penentuan lokasi penelitian dilakukan secara sengaja (purposive) dengan pertimbangan bahwa Koperasi Tirto Kencono merupakan koperasi pertanian terbesar di Kecamatan Air Naningan dan memanfaatkan hasil usahatani para anggotanya yaitu petani kopi hutan rakyat untuk diolah menjadi produk-produk unggulan koperasi dan merupakan ciri khas dari Desa Talang 20.

Responden yang diamati adalah ketua koperasi, enam orang tenaga kerja dan 10 anggota koperasi yang mengadakan bahan baku dalam proses pengolahan kopi robusta di Koperasi Tirto Kencono untuk mendapatkan informasi yang terkait produk-produk olahan kopi. Pengumpulan data dilakukan pada bulan Februari 2019. Produk olahan yang dihasilkan unit usaha ada empat yaitu Roastbean Robusta T20, Green Coffee T20, Fine Robusta T20 dan Gendis Coffee T20.

Data yang dikumpulkan pada penelitian ini adalah data primer dan data sekunder. Data primer diperoleh melalui wawancara menggunakan kuisioner dan pengamatan langsung tentang kegiatan di lapangan. Data sekunder diperoleh dari lembaga/instansi terkait seperti Dinas Koperasi dan UMKM Provinsi Lampung, Badan Pusat Statistik, Dinas Perkebunan dan Peternakan Kabupaten Tanggamus. Metode analisis data yang digunakan pada penelitian ini adalah analisis deskriptif kuantitatif. 
Metode analisis deskriptif kuantitatif digunakan untuk menjawab tujuan penelitian yang pertama yaitu menganalisis besarnya pendapatan masingmasing produk olahan kopi robusta menggunakan teori dari Soekartawi (2000) yaitu :

$\pi=\mathrm{TR}-\mathrm{TC}$

$\mathrm{C}=$ Y.Py $-\Sigma$ Xi.PXi-BTT.

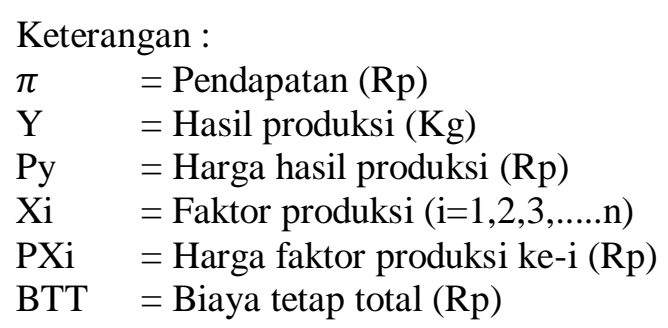

Selain biaya tunai dan biaya diperhitungkan, terdapat biaya lainnya yang dikeluarkan dalam proses produksi adalah biaya bersama (join cost). Biaya bersama digunakan untuk menghitung penyusutan alat, biaya listrik, biaya pajak, biaya tenaga kerja langsung, biaya gas dan biaya sewa bangunan yang dikeluarkan masing-masing produk. Metode join cost yang digunakan adalah metode nilai jual relatif saat harga jual diketahui pada titik impas. Metode biaya bersama menggunakan teori dari Mulyadi (2009) yaitu :

Alokasi join cost $=$
$\frac{\Sigma \text { nilai jual masing-masing produk }}{\Sigma \text { nilai jual keseluruhan produk }} \times$ biaya bersama.

Untuk mengetahui suatu usaha menguntungkan atau tidak secara ekonomi dapat dianalisis dengan menggunakan nisbah atau perbandingan antara penerimaan dengan biaya (Revenue Cost Ratio) yaitu :

$\mathrm{R} / \mathrm{C}=\mathrm{TR} / \mathrm{TC}$.

Keterangan :

$\mathrm{R} / \mathrm{C}=$ Nisbah penerimaan dan biaya

$\mathrm{TR}=$ Total revenue atau penerimaan total $(\mathrm{Rp})$

$\mathrm{TC}=$ Total cost atau biaya total $(\mathrm{Rp})$

Kriteria pengambilan keputusan adalah :

1. Jika $R / C>1$, maka suatu usaha mengalami keuntungan

2. Jika $\mathrm{R} / \mathrm{C}<1$, maka suatu usaha mengalami kerugian

3. Jika $\mathrm{R} / \mathrm{C}=1$, maka suatu usaha mengalami impas (Soekartawi 2000).
Metode analisis deskriptif kuantitatif digunakan untuk menjawab tujuan kedua yaitu menganalisis besarnya profitabilitas masing-masing produk olahan kopi robusta dengan menggunakan metode Downey dan Erickson (1992) yaitu :

Profitabilitas $=\frac{\pi}{\text { Penerimaan }} \times 100 \%$

Keterangan :

$\pi=$ Pendapatan usaha koperasi olahan kopi robusta.

Kriteria pengambilan keputusan adalah:

1. Profitabilitas $>0$ berarti usaha yang dilakukan menguntungkan.

2. Profitabilitas $\leq 0$ berarti usaha yang dilakukan tidak menguntungkan.

\section{HASIL DAN PEMBAHASAN}

\section{Gambaran Umum Koperasi Tirto Kencono}

Koperasi Tirto Kencono berada di Dusun Talang 20, Pekon Air Naningan, Kecamatan Air Naningan, Kabupaten Tanggamus. Koperasi Tirto Kencono didirikan pada tahun 2013 dan memulai kegiatan pengolahan kopi pada tahun 2016. Koperasi Tirto Kencono memiliki empat unit usaha yaitu unit pengolahan kayu hutan rakyat, unit pengolahan madu alam, unit usaha kerajinan hasil hutan rakyat kayu maupun non kayu dan unit usaha pengolahan kopi. Unit usaha pengolahan kopi memulai kegiatan tahun 2016 dan semakin tahun mengalami perkembangan.

\section{Karakteristik Responden}

Responden dalam penelitian ini adalah ketua koperasi yaitu ibu Sri Rejeki berusia 56 tahun dengan pendidikan formal terakhir yaitu SMP. Ketua memiliki pengalaman kerja selama 13 tahun sebagai petani dengan produksi utama adalah kopi dan produksi sampingan adalah lada. Tenaga kerja yang dijadikan sebagai responden dalam penelitian sebanyak enam orang, dimana dua orang tenaga kerja pria dan empat orang tenaga kerja wanita. Pembagian pekerjaan untuk setiap tenaga kerja pria dan wanita berbeda-beda, terdapat satu orang tenaga kerja yang melakukan pekerjaan satu sampai dua pekerjaan. Tenaga kerja pria melakukan pekerjaan seperti penjemuran, penggilingan kopi kering, pengovenan, pengayakan dan penggilingan kopi menjadi bubuk. Tenaga kerja wanita melakukan pekerjaan seperti sortir basah, pencucian, sortir biji, penambahan gula semut dan pengemasan. 
Anggota koperasi yang dijadikan sebagai responden selanajutnya adalah anggota yang melakukan pengadaan bahan baku kopi robusta di unit usaha pengolahan kopi. Pada musim panen tahun 2018, dari 32 anggota koperasi hanya 10 anggota yang memasok hasil panennya yang terdiri dari 8 anggota pria dan 2 anggota wanita. Para anggota tersebut merupakan petani kopi robusta hutan rakyat di Dusun Talang 20 Pekon Air Naningan.

Para anggota tergolong dalam usia produktif yaitu kisaran umur produktif adalah 15-65 tahun. Ratarata luas lahan yang dimiliki para anggota adalah 2-5 hektar. Produksi yang dihasilkan adalah 600$1.200 \mathrm{~kg}$ kopi basah dan tingkat pendidikan yang dimiliki oleh ketua koperasi dan anggota beragam mulai dari SD, SMP dan SMA. Namun hal tersebut tidak menjadi pengaruh untuk jalannya pengolahan kopi robusta di Koperasi Tirto Kencono, karena kegitan didalamnya cukup mudah dan tidak memerlukan keterampilan khusus.

\section{Proses Pengolahan Produk Kopi Robusta}

Unit pengolahan kopi robusta di Koperasi Tirto Kencono menggunakan bahan baku yang berbedabeda untuk menghasilkan empat produk unggulan. Koperasi mengutamakan bagi produk mereka untuk menggunakan kopi robusta petik merah, agar kualitas produk baik dari segi fisik maupun aroma. Produk Fine Robusta T20 dan Roastbean Robusta T20 menggunakan bahan baku kopi petik merah, Green Coffee T20 dengan bahan baku kopi petik hijau dan Gendis Coffee T20 dengan bahan baku kopi petik campuran

Untuk menghasilkan olahan kopi robusta dengan kualitas terbaik, unit pengolahan kopi robusta di Koperasi Tirto Kencono melakukan berbagai aktivitas tertentu mulai dari proses sortir basah hingga produk siap dikemas. Tahap-tahap proses penerimaan dan pengolahan kopi robusta di Koperasi Tirto Kencono disajikan pada Gambar 1. Produk Fine Robusta T20 dijual dengan harga Rp $150.000 / \mathrm{kg}$ atau $\mathrm{Rp} 45.000 / 200$ gram dalam bentuk kopi bubuk, karena melewati proses penggilingan biji sangrai. Produk Roastbean Robusta T20 dijual

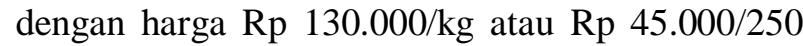
gram tidak melalui proses penggilingan biji kopi, karena produk yang dijual dalam bentuk biji kopi yang telah disangrai. Produk Green Coffee T20 yang dijual dengan harga Rp 350.000/kg atau Rp 75.000/200 gram dalam bentuk kopi giling kasar. Produk Gendis Coffee T20 dijual dengan harga Rp
$130.000 / \mathrm{kg}$ atau $\mathrm{Rp} 15.000 / 75$ gram dalam bentuk biji kopi yang telah disangrai.

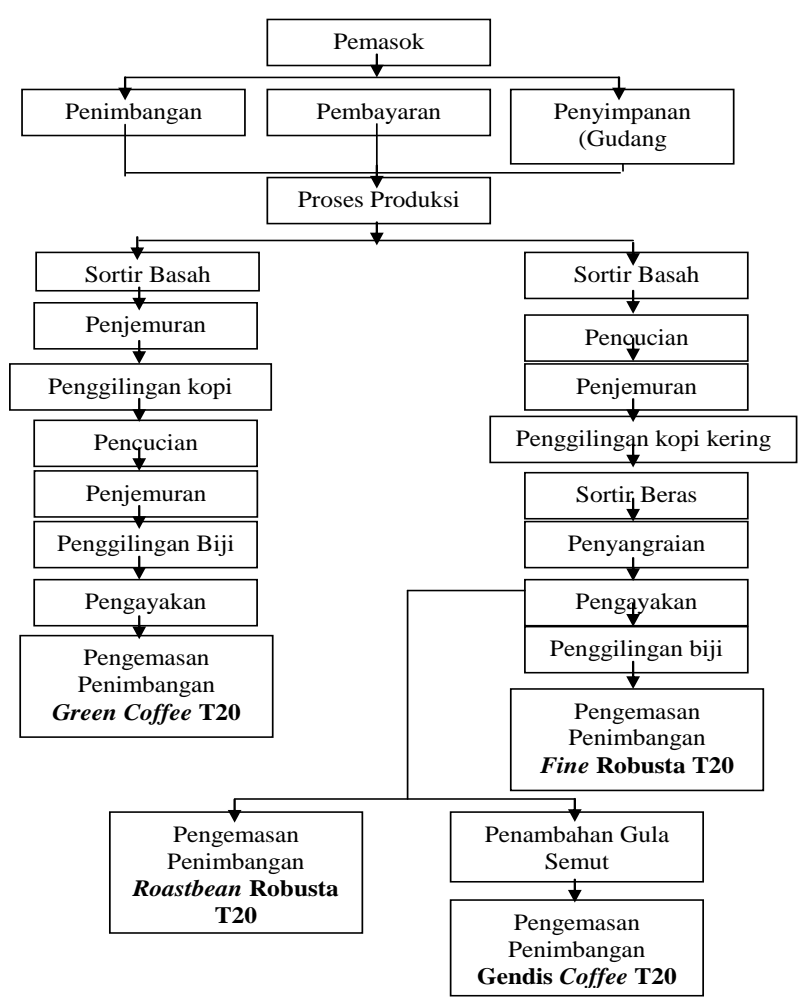

Gambar 1. Proses penerimaan bahan baku pada proses pengolahan kopi robusta di Koperasi Tirto Kencono

\section{Analisis Pendapatan}

Menurut Soekartawi (1995), pendapatan adalah selisih antara penerimaan dengan semua biaya yang dikeluarkan selama melakukan kegiatan usaha. Unit usaha melakukan produksi sebanyak empat kali dalam sebulan, dimana setiap minggu melakukan produksi empat produk tersebut. Total penerimaan selama periode satu bulan dari keempat produk sebesar Rp 25.175.000,00 dengan biaya yang dikeluarkan sebesar Rp 12.852567,70. Meskipun penerimaan lebih tinggi dibandingkan biaya yang harus dikeluarkan, sehingga diperoleh pendapatan yang bersifat positif. Hasil tersebut sesuai dengan penelitian Marlina, Dharmawan dan Purnamadewi (2017) mengenai peranan kopi rakyat terhadap perekonomian wilayah Kabupaten Lampung Barat.

Biaya produksi yang dikeluarkan bagi keempat produk olahan kopi robusta terdiri dari dua jenis biaya, yaitu biaya tunai dan biaya diperhitungkan. Biaya tunai terdiri dari biaya bahan baku, biaya bahan penunjang, biaya tenaga kerja luar keluarga, biaya listrik dan biaya pajak. Biaya 
diperhitungkan terdiri dari biaya penyusutan alat dan biaya sewa bangunan.

Biaya lainnya yang dikeluarkan dalam proses produksi adalah biaya bersama (join cost). Menurut Mulyadi (2009), biaya bersama adalah biaya produksi bersama yang dikeluarkan dalam proses produksi dimana akan menghasilkan berbagai macam produk. Perhitungan biaya bersama berdasarkan penerimaan yang diperoleh masing-masing produk dan digunakan untuk penyusutan alat, biaya gas, biaya pajak, biaya listrik dan biaya sewa bangunan, sehingga akan mengetahui alokasi penggunaan masing-masing produk.

Alokasi join cost biaya listrik, biaya pajak dan biaya sewa bangunan terhadap produk Fine Robusta T20, Roastbean Robusta T20, Green Coffee T20 dan Gendis Coffee T20 berturut-turut sebesar $27,81 \%, 19,26 \%, 37,24 \%$ dan $15,49 \%$. Biaya gas untuk Fine Robusta T20, Roastbean
Robusta T20 dan Gendis Coffee T20 masingmasing adalah 44,30\%, 31,01\% dan 24,68\%. Produk Green Coffee T20 tidak memiliki alokasi join cost gas, karena dalam proses produksinya tidak menggunakan gas.

Analisis pendapatan untuk keempat produk dapat dihasilkan dari penggunaan bahan baku setiap produk pada saat penelitian dan penggunaaan bahan baku per $100 \mathrm{~kg}$. Analisis pendapatan dari penggunaan bahan baku setiap produk olahan kopi robusta pada saat penelitian disajikan pada Tabel 1 . Tabel 1 menyajikan pendapatan yang diperoleh masing-masing produk dari penggunaan bahan baku saat penelitian. Keempat produk memiliki nilai $\mathrm{R} / \mathrm{C}>1$, sehingga unit usaha dalam menghasilkan keempat produk menguntungkan dan layak untuk dijalankan. Produk yang memiliki R/C tertinggi berturut-turut adalah Green Coffee T20, Fine Robusta T20, Roastbean Robusta T20 dan Gendis Coffee T20.

Tabel 1. Pendapatan olahan kopi robusta di Koperasi Tirto Kencono

\begin{tabular}{|c|c|c|c|c|c|c|c|}
\hline No & Uraian & Satuan & $\begin{array}{c}\text { Fine Robusta } \\
\text { T20 }\end{array}$ & $\begin{array}{c}\text { Roastbean } \\
\text { Robusta T20 }\end{array}$ & $\begin{array}{c}\text { Green Coffee } \\
\text { T20 }\end{array}$ & $\begin{array}{c}\text { Gendis Coffee } \\
\text { T20 }\end{array}$ & Total \\
\hline \multirow[t]{3}{*}{1} & Produksi & Bungkus & 200,00 & 140,00 & 125,00 & 260,00 & \\
\hline & Harga & Rp/Bungkus & $35.000,00$ & $35.000,00$ & $75.000,00$ & $15.000,00$ & \\
\hline & Penerimaan & $\mathrm{Rp}$ & $7.000 .000,00$ & $4.900 .000,00$ & $9.375 .000,00$ & $3.900 .000,00$ & $25.175 .000,00$ \\
\hline \multirow[t]{15}{*}{2} & Biaya Produksi & & & & & & \\
\hline & 1. Biaya Tunai & & & & & & \\
\hline & Bahan Baku & $\mathrm{Rp}$ & $1.540 .000,00$ & $1.347 .500,00$ & $577.500,00$ & $539.000,00$ & $4.004 .000,00$ \\
\hline & Gas* & Tabung & $29.240,51$ & $20.468,35$ & 0,00 & $16.291,14$ & $66.000,00$ \\
\hline & Gula Semut & $\mathrm{Kg}$ & 0,00 & 0,00 & 0,00 & $300.000,00$ & $300.000,00$ \\
\hline & Kemasan & Unit & $1.040 .000,00$ & $728.000,00$ & $650.000,00$ & $1.352 .000,00$ & $3.770 .000,00$ \\
\hline & Pajak* & $\mathrm{Rp}$ & 463,42 & 324,40 & 620,66 & 258,19 & $1.666,67$ \\
\hline & Listrik* & $\mathrm{Rp}$ & $55.610,72$ & $38.927,51$ & $74.478,65$ & $30.983,12$ & $200.000,00$ \\
\hline & Tenaga Kerja Langsung & $\mathrm{HOK}$ & $1.457 .600,00$ & $1.118 .010,00$ & $623.500,00$ & $738.800,00$ & $3.937 .910,00$ \\
\hline & Total Biaya Tunai & $\mathrm{Rp}$ & $4.122 .914,65$ & $3.253 .230,26$ & $1.926 .099,30$ & $2.977 .332,45$ & $12.279 .576,67$ \\
\hline & 2. Biaya Diperhitungkan & & & & & & \\
\hline & Penyusutan Alat* & $\mathrm{Rp}$ & $91.288,51$ & $56.764,52$ & $84.187,83$ & $49.083,50$ & $281.324,37$ \\
\hline & Sewa Lahan* & $\mathrm{Rp}$ & $81.098,97$ & $56.769,28$ & $108.614,70$ & $45.183,71$ & $291.666,67$ \\
\hline & Total Biaya Diperhitungkan & $\mathrm{Rp}$ & $172.387,49$ & $113.533,81$ & $192.802,52$ & $94.267,22$ & $572.991,04$ \\
\hline & Total Biaya & $\mathrm{Rp}$ & $4.295 .302,14$ & $3.366 .764,06$ & $2.118 .901,83$ & $3.071 .599,67$ & $12.852 .567,70$ \\
\hline \multirow[t]{3}{*}{3} & Pendapatan & & & & & & \\
\hline & Pendapatan Atas Biaya Tunai & $\mathrm{Rp}$ & $2.877 .085,35$ & $1.646 .769,74$ & $7.448 .900,70$ & $922.667,55$ & $12.895 .423,33$ \\
\hline & Pendapatan Atas Biaya Total & $\mathrm{Rp}$ & $2.704 .697,86$ & $1.533 .235,94$ & 7.256.098,17 & $828.400,33$ & $12.322 .432,30$ \\
\hline \multirow[t]{3}{*}{4} & $\mathrm{R} / \mathrm{C}$ & & & & & & \\
\hline & R/C Atas Biaya Tunai & $\mathrm{Rp}$ & 1,70 & 1,51 & 4,87 & 1,31 & \\
\hline & R/C Atas Biaya Total & $\mathrm{Rp}$ & 1,63 & 1,46 & 4,42 & 1,27 & \\
\hline
\end{tabular}


Tabel 1 memperlihatkan bahwa pendapatan tertinggi diperoleh dari produk Green Coffee T20. Pendapatan atas biaya tunai dan biaya total terbesar diperoleh dari produk Green Coffee T20 sebesar Rp 7.448.900,70 dan Rp 7.256.098,17. Nilai R/C atas biaya tunai sebesar 4,87 artinya setiap Rp 10.000,00 uang yang dikeluarkan oleh Koperasi Tirto Kencono, maka koperasi tersebut mendapatkan keuntungan sebesar $\mathrm{Rp}$ 48.700,00. Nilai R/C atas biaya total sebesar 4,42 artinya setiap Rp 10.000,00 uang yang dikeluarkan oleh Koperasi Tirto Kencono, maka koperasi tersebut mendapatkan keuntungan sebesar Rp 44.200,00.

Pendapatan terendah diperoleh produk Gendis Coffee T20 dengan pendapatan atas biaya tunai dan biaya total sebesar $\mathrm{Rp} 922.667,55$ dan $\mathrm{Rp}$ 828.400,33. Nilai R/C atas biaya tunai sebesar 1,31 artinya setiap $\mathrm{Rp} 10.000,00$ uang yang dikeluarkan oleh Koperasi Tirto Kencono, maka koperasi tersebut mendapatkan keuntungan sebesar Rp 13.100,00. Nilai R/C atas biaya total sebesar 1,27 artinya setiap $\mathrm{Rp} 10.000,00$ uang yang dikeluarkan oleh Koperasi Tirto Kencono, maka koperasi tersebut mendapatkan keuntungan sebesar $\mathrm{Rp}$ 12.700,00. Hasil penelitian sejalan dengan penelitian yang dilakukan Putri (2010), bahwa agroindustri kopi bubuk organik di Desa Gunung Terang Kecamatan Way Lenong Kabupaten Lampung Barat layak untuk dilaksanakan.

Analisis pendapatan pada penelitian ini dapat diperoleh dengan penggunaan bahan baku per 100 kg. Perhitungan pendapatan tersebut dengan tujuan untuk membandingkan $\mathrm{R} / \mathrm{C}$ yang dihasilkan keempat produk dengan penggunaan bahan baku yang sama. Analisis pendapatan dari penggunaan bahan baku setiap produk olahan kopi robusta per $100 \mathrm{~kg}$ disajikan pada Tabel 2.

Tabel 2. Pendapatan olahan kopi robusta dengan penggunaan bahan baku $100 \mathrm{~kg}$

\begin{tabular}{|c|c|c|c|c|c|c|c|}
\hline No & Uraian & Satuan & $\begin{array}{c}\text { Fine Robusta } \\
\text { T20 }\end{array}$ & $\begin{array}{c}\text { Roastbean } \\
\text { Robusta T20 }\end{array}$ & $\begin{array}{c}\text { Green } \\
\text { Coffee } \mathrm{T} 20\end{array}$ & $\begin{array}{c}\text { Gendis Coffee } \\
\text { T20 }\end{array}$ & Total \\
\hline \multirow[t]{3}{*}{1} & Produksi & Bungkus & 65,00 & 52,00 & 65,00 & 169,00 & \\
\hline & Harga & Rp/Bungkus & $35.000,00$ & $35.000,00$ & $75.000,00$ & $15.000,00$ & \\
\hline & Penerimaan & $\mathrm{Rp}$ & $2.272 .727,27$ & $1.818 .181,82$ & $4.870 .129,87$ & $2.532 .467,53$ & $11.493 .506,49$ \\
\hline \multirow[t]{15}{*}{2} & Biaya Produksi & & & & & & \\
\hline & 1. Biaya Tunai & & & & & & \\
\hline & Bahan Baku & $\mathrm{Rp}$ & $500.000,00$ & $500.000,00$ & $300.000,00$ & $350.000,00$ & $1.650 .000,00$ \\
\hline & Gas* & Tabung & $9.493,67$ & $7.594,94$ & 0,00 & $194.805,19$ & $211.893,80$ \\
\hline & Gula Semut & $\mathrm{Kg}$ & 0,00 & 0,00 & 0,00 & $10.578,66$ & $10.578,66$ \\
\hline & Kemasan & Unit & $337.662,34$ & $270.129,87$ & $337.662,34$ & $877.922,08$ & $1.823 .376,62$ \\
\hline & Pajak* & $\mathrm{Rp}$ & 150,46 & 120,37 & 322,42 & 167,66 & 760,91 \\
\hline & Listrik* & $\mathrm{Rp}$ & $18.055,43$ & $14.444,34$ & $38.690,21$ & $20.118,91$ & $91.308,89$ \\
\hline & Tenaga Kerja Langsung & HOK & $473.246,75$ & $414.846,01$ & $323.896,10$ & $479.740,26$ & $1.691 .729,13$ \\
\hline & Total Biaya Tunai & $\mathrm{Rp}$ & $1.338 .608,65$ & $1.207 .135,53$ & $1.000 .571,07$ & $1.933 .332,76$ & $5.479 .648,01$ \\
\hline & 2. Biaya Diperhitungkan & & & & & & \\
\hline & Penyusutan Alat* & $\mathrm{Rp}$ & $29.639,13$ & $21.062,90$ & $43.733,94$ & $31.872,41$ & $126.308,37$ \\
\hline & Sewa Lahan* & $\mathrm{Rp}$ & $26.330,84$ & $21.064,67$ & $56.423,22$ & $29.340,07$ & $133.158,80$ \\
\hline & Total Biaya Diperhitungkan & $\mathrm{Rp}$ & $55.969,96$ & $42.127,57$ & $100.157,16$ & $61.212,48$ & $259.467,17$ \\
\hline & Total Biaya & $\mathrm{Rp}$ & $1.394 .578,62$ & $1.249 .263,10$ & $1.100 .728,22$ & $1.994 .545,24$ & $5.739 .115,18$ \\
\hline \multirow[t]{3}{*}{3} & Pendapatan & & & & & & \\
\hline & Pendapatan Atas Biaya Tunai & $\mathrm{Rp}$ & $934.118,62$ & $611.046,29$ & $3.869 .558,80$ & $599.134,77$ & $6.013 .858,48$ \\
\hline & Pendapatan Atas Biaya Total & $\mathrm{Rp}$ & $878.148,66$ & $568.918,72$ & $3.769 .401,65$ & $537.922,29$ & $5.754 .391,31$ \\
\hline \multirow[t]{3}{*}{4} & $\mathrm{R} / \mathrm{C}$ & & & & & & \\
\hline & R/C Atas Biaya Tunai & $\mathrm{Rp}$ & 1,70 & 1,51 & 4,87 & 1,31 & \\
\hline & R/C Atas Biaya Total & $\mathrm{Rp}$ & 1,63 & 1,46 & 4,42 & 1,27 & \\
\hline
\end{tabular}


Hasil analisis pendapatan pada Koperasi Tirto Kencono menunjukkan bahwa besarnya pendapatan yang diperoleh berbeda setiap jenisnya. Hal ini terlihat dari pendapatan yang diperoleh, baik pendapatan atas biaya tunai dan biaya total masing-masing jenis olahan kopi. Berdasarkan analisis pendapatan pada Tabel 2 dapat dilihat bahwa pendapatan atas biaya total dari ke empat produk olahan kopi robusta di Koperasi Tirto Kencono jika dijumlah sebesar Rp 5.754.391,31 per $100 \mathrm{~kg}$ bahan baku.

Berdasarkan Tabel 2 pendapatan atas biaya total tertinggi berasal dari produk Green Coffee T20 sebesar Rp 3.869.558,80 per $100 \mathrm{~kg}$ bahan baku. Meskipun permintaan akan produk Green Coffee T20 lebih sedikit dibandingkan dengan produk lainnya, tetapi harga jual lebih tinggi daripada olahan kopi lainnya, yaitu Rp 75.000 per 200 kopi. Pendapatan atas biaya total terkecil diperoleh produk Gendis Coffee T20 sebesar Rp 599.134,77 per $100 \mathrm{~kg}$ bahan baku. Kecilnya pendapatan yang diperoleh Gendis Coffee T20 dikarenakan harga jual produk dan kemasan yang digunakan paling kecil dibandingkan produk lainnya yaitu sebesar Rp 15.000,00 per 75 gram.

Pendapatan atas biaya tunai terbesar diperoleh produk Green Coffee T20 sebesar Rp 3.869.558,80 per $100 \mathrm{~kg}$ bahan baku. Pendapatan atas biaya tunai terkecil diperoleh produk Gendis Coffee T20 sebesar Rp 599.134,77 per kg bahan baku. Pendapatan atas biaya total dan biaya tunai yang dihasilkan produk Gendis Coffee T20 berbeda karena total biaya tunai lebih besar dibandingkan total biaya sebelum dikurangi dengan penerimaan yang diperoleh dari penjualan produk Gendis Coffee T20.

Analisis pendapatan olahan kopi robusta di Koperasi Tirto Kencono juga dapat digunakan untuk melihat apakah unit usaha sudah menguntungkan atau belum menguntungkan. Dilihat dari nisbah penerimaan $(\mathrm{R} / \mathrm{C})$ terhadap biaya tunai dan biaya total dengan penggunaan bahan baku yang sama sebesar $100 \mathrm{~kg}$. Nilai R/C yang diperoleh dari penggunaan bahan baku setiap produk pada saat penelitian dan penggunaaan bahan baku per $100 \mathrm{~kg}$ adalah sama, yang membedakan adalah pendapatan serta biaya-biaya yang dikeluarkan untuk masing-masing produk. Tabel 2 menunjukkan dengan penggunaan bahan baku yang sama sebanyak $100 \mathrm{~kg}$, ke empat produk sudah menguntungkan dan layak untuk dijalankan. Hasil penelitian ini sejalan dengan penelitian Akbar (2019), bahwa Agroindustri Kopi Bubuk Cap Obor Mas Lampung per 100 kg bahan baku sudah menguntungkan untuk diusahakan karena memiliki nilai R/C lebih dari satu.

\section{Analisis Profitabilitas}

Profitabilitas dapat dihitung dengan mengetahui persentase perbandingan yang didapat dari keuntungan dengan penjualan atau penerimaan. Profitabilitas yang dihitung untuk keempat produk yang dihasilkan oleh Koperasi Tirto Kencono pada penelitian ini merupakan pendapatan usaha pengolahan kopi robusta pada periode produksi Januari-Februari 2019.

Rasio profitabilitas merupakan besarnya kemampuan suatu usaha dalam menghasilkan keuntungan. Profitabilitas pada olahan kopi robusta di Koperasi Tirto Kencono dengan penggunaan bahan baku pada saat penelitian untuk masing-masing produk dapat dilihat pada Tabel 3. Tabel 3 menunjukkan bahwa dari keempat produk Koperasi Tirto Kencono, rasio profitabilitas tertinggi didapatkan dari produk Green Coffee T20, selanjutnya Fine Robusta T20, Roastbean Robusta T20 dan Gendis Coffee T20. Menurut Downey dan Erickson (1992), apabila memiliki nilai profitabilitas lebih dari $0 \%$ menguntungkan dan layak untuk dijalankan.

Tabel 4 memperlihatkan dengan menggunakan bahan baku yang sama sebesar $100 \mathrm{~kg}$ untuk masing-masing produk memberikan kesimpulan bahwa biji kopi robusta jika diolah menjadi produk Green Coffee T20 lebih menguntungkan dibandingkan dengan mengolahnya menjadi produk lainnya, karena nilai profitabilitas yang diperoleh sebesar 77,40\%.

Tabel 3. Rasio profitabilitas pada olahan kopi robusta di Koperasi Tirto Kencono dengan bahan baku pada saat penelitan

\begin{tabular}{lccc}
\hline \multicolumn{1}{c}{ Produk } & $\begin{array}{c}\text { Penerimaan } \\
(\mathrm{Rp})\end{array}$ & $\begin{array}{c}\text { Keuntungan } \\
(\mathrm{Rp})\end{array}$ & $\begin{array}{c}\text { Profita- } \\
\text { bilitas } \\
(\%)\end{array}$ \\
\hline Fine Robusta T20 & $7.000 .000,00$ & 2.704 .697 .86 & 38,64 \\
$\begin{array}{l}\text { Roastbean Robusta } \\
\text { T20 }\end{array}$ & $4.900 .000,00$ & $1.533 .235,94$ & 31,29 \\
Green Coffee T20 & $9.375 .000,00$ & $7.256 .098,17$ & 77,40 \\
Gendis Coffee T20 & $3.900 .000,00$ & $828.400,33$ & 21,24 \\
\hline
\end{tabular}


Tabel 4. Rasio profitabilitas pada olahan kopi robusta di Koperasi Tirto Kencono dengan bahan baku per $100 \mathrm{~kg}$

\begin{tabular}{|c|c|c|c|}
\hline Produk & $\begin{array}{l}\text { Penerimaan } \\
\text { (Rp) }\end{array}$ & $\begin{array}{l}\text { Keuntungan } \\
\text { (Rp) }\end{array}$ & $\begin{array}{c}\text { Profita- } \\
\text { bilitas } \\
(\%)\end{array}$ \\
\hline Fine Robusta T20 & $2.272 .727,27$ & $878.149,66$ & 38,64 \\
\hline $\begin{array}{l}\text { Roastbean } \\
\text { Robusta T20 }\end{array}$ & $1.818 .181,82$ & $568.918,72$ & 31,29 \\
\hline Green Coffee T20 & $4.870 .129,87$ & $3.769 .401,65$ & 77,40 \\
\hline $\begin{array}{l}\text { Gendis Coffee } \\
\text { T20 }\end{array}$ & $2.532 .467,53$ & $537.922,29$ & 21,24 \\
\hline
\end{tabular}

Tabel 4 juga memperlihatkan profitabilitas yang diperoleh masing-masing produk lebih dari $0 \%$, sehingga dengan penggunaan bahan baku yang sama untuk masing-masing produk menguntungkan dan layak untuk dijalankan. Penelitian ini sejalan dengan penelitian yang dilakukan oleh Yurhaya dan Rustam (2016) yang menerangkan bahwa nilai profitabilitas yang diperoleh usaha kopi bubuk pada industri Bumi Mutiara sebesar $36,25 \%$, yang artinya lebih dari $0 \%$ sehingga menguntungkan dan layak untuk dijalankan.

\section{KESIMPULAN}

Pendapatan yang diperoleh dari keempat produk olahan kopi robusta di Koperasi Tirto Kencono sudah menguntungkan dan layak dijalankan, karena R/C yang diperoleh lebih dari satu. Nilai rasio profitabilitas keempat produk yang diperoleh lebih dari 0\%, maka usaha pengolahan kopi robusta yang dilakukan Koperasi Tirto Kencono menguntungkan dan layak untuk dijalankan.

\section{DAFTAR PUSTAKA}

Akbar TR. 2019. Analisis keragaan dan risiko sistem agroindustri kopi bubuk (Studi kasus Agroindustri Kopi Bubuk Cap Obor Mas Lampung, Kecamatan Kotabumi Kota,
Lampung, Kecamatan Kotabumi Kota, Kabupaten Lampung Utara). Skripsi. Universitas Lampung. Bandar Lampung.

BPS [Badan Pusat Statistik]. 2016. Jumlah Koperasi Aktif Menurut Provinsi Tahun 20062016. Badan Pusat Statistik. Jakarta.

Dinas Koperasi dan UKM Provinsi Lampung. 2018. Sebaran Jumlah Koperasi di Provinsi Lampung Berdasarkan Status Keaktifan Per Kabupaten. Dinas Koperasi dan UKM Provinsi Lampung. Bandar Lampung.

Dinas Perkebunan dan Peternakan Kabupaten Tangamus. 2017. Luas Panen dan Produksi Tanaman Perkebunan di Kecamatan Air Naningan Tahun 2017. Dinas Perkebunan dan Peternakan Kabupaten Tanggamus. Kota Agung.

Downey WD dan Erickson SP. 1992. Manajemen Agribisnis. Erlangga. Jakarta.

Marlina L, Dharmawan AH, dan Purnamadewi YL. 2017. Peranan kopi rakyat terhadap perekonomian wilayah Kabupaten Lampung Barat. JIIA, 5 (3) : 298-299. http://jurnal.fp. unila.ac.id/index.php/JIA/article/download/17 59/1559. [ 05 Juli 2019].

Mulyadi. 2009. Akuntansi Biaya. Edisi Kelima. Cetakan ke sembilan. Unit Penerbitan dan Percetakan Sekolah Tinggi Ilmu Manajemen YKPN Universitas Gajah Mada. Yogyakarta.

Putri RN. 2010. Analisis nilai tambah, kelayakan finansial, dan strategi pengembangan Agroindustri Kopi Bubuk Organik di Desa Gunung Terang Kecamatan Way Tenong Kabupaten Lampung Barat (Studi kasus pada Perusahaan Waroeng Organik). Skripsi. Universitas Lampung. Bandar Lampung.

Soekartawi. 1995. Analisis Usahatani. UI Press. Jakarta.

2000. Pengantar Agroindustri. PT Raja Grafindo Persada. Jakarta.

Yurhaya dan Rustam AR. 2016. Analisis profitabilitas usaha kopi bubuk pada Industri Bumi Mutiara di Kota Palu. Jurnal Agroland, 23 (2) : 149-156. http://jurnal.untad.ac.id/ jurnal/index.php/AGROLAND/article/view/8 221/6518. [10 Juli 2019]. 